\title{
Factor Analysis of Human Resource Practices in Nepalese Insurance Companies Raju Kumar Rai*
}

\begin{abstract}
s
This study is focused on the human resource practice is pertinent to all type of organizations, regardless of its nature, size and scope. Organization must ensure appropriate human resource practice to operate and succeed in the business. Employees' from Nepalese insurance companies has been regarded as sample to explore the study on human resource practice. The result showed four factors prevailing in this sector.
\end{abstract}

Key Words: Size, Employee, Human Resources practice, insurance companies

*M.Phil. (Management), Lecturer at Saraswoti Multiple Campus, Tribhuvan University. Email: happyheartbrt@gmail.com, Currently Ph.D scholar at Tribhuvan University. 


\section{Background of the study}

\section{Introduction}

Human Resource, unique and vital by its nature, is an inevitable part of any organization. Human resource is valuable and dynamic at the same time. Human Resource Management practices, popularly known as Human Resource practices (HR practice) have been changed radically during the last two decades due to globalization, privatization/deregulation, competition and technological advancements. Success in today's competitive business depends less on advantages associated with economies of scale, sophisticated technology, goodwill but are more relied on human resources and high concern of human resource management practices. This highly unstable environment has put on organisations to adopt suitable HR practices that augment persistent level of high performance. Organizations require hiring right person for the right job at the right time to grab organizational opportunities in the face of competition. In fact, the overall performance of any organization depends upon the degree to which human resource is successfully utilized. The success and sustainability of any organization depend on how effectively they manage suitable human resource practices in a distinctive culture, area and situation. However, very limited number of studies has been conducted on HR practices in the context of developing countries in general. This study has been conducted to identify the factors of HR practices with reference to Nepalese insurance industry.

In Nepal, the concept of HRM ascended after the liberalization and privatization policy in 1990. Prior to 1990, human resource management practices were not satisfactory in the majority of the organizations because of the reasons of such as not so precisely defined strategies in public enterprises, poor state of employee participation, distorted communication system between employees and managers due to hierarchic nature of organizations and thus feeling of status and prestige was high among the top level managers and lacked systematic HR planning (Upadhyaya, 1981); (Koirala, 1989); (Agrawal, 1983); (Tiwari, 1984). Employees believed that nepotism and favouritism were widespread in the recruitment and selection process, decision making practice was highly centralised even to deal with minor HR responsibilities, jobs were not so challenging for managers and the reward system was not properly linked with performance (Shrestha, 1991); (Paudel, 1992); (Adhikari, 1992).

Establishment of private business organizations and joint ventures after 1990 gave a new avenue to Nepalese business organizations. It was after the period when organizations were found to be emphasizing on the performance and the practice of paying competitive compensation to the competent employees were started slowly. In Nepal, personnel management is still believed to be pre-occupied with record keeping and operational issues rather than managerial ones (Adhikari, 2008). Training and development programmes were highly practiced as means to develop employees' skills and knowledge (Adhikari's study, cited in Adhikari and Gautam, 2011). However, the Nepali organizations are still on learning phase and thus the foundation of HRM is not yet clearly established. In order to fulfil the need of skilled manpower in corporations, higher education in business administration and management has been widely proliferated (Adhikari, 2004). More recently, some developments have been seen in the use of computerised HR information, recruitment of qualified and skilled manpower, interest in the training and development of employees and the like. However, in Nepalese workplaces most prominent HR related issues and problems are: unproductive staff, lack of corporate culture, lack of mechanism to implement labour legislations, low degree of integration and coordination of different business functions, lack of performance based pay system, distorted flow of communication and information, low level of pay and rising absenteeism, proliferating union activities (Adhikari, 2010). Organizations unable to complying provision of labour Acts, the role of personnel department is negligible in different HR related matters such as recruitment and selection, training and development and performance evaluation and its implication for career development of employees is not properly understood (Adhikari and Gautam, 
2010). At national level, there is lack of job opportunities for university graduates on the one hand and in the lack of requisite skills to work on newly created jobs on the other hand (Pant, 1993).

\section{Statement of the Problem}

There is no different opinion to the employees' contribution on the existence and operation of any organization. In fact they are the inevitable part and major determinant of success and failure of the organization. Good organizational practice leads to the success of the business whereas bad practices not only makes the organizational failure but has to extinguish from the existence. Since employees are the basic resource and requirement, organization must be capable enough to recruit, select, train, compensate, benefit, retain, secure and recognize them. Good human resource practice leads to successful attainment of organizational goal. But, some major issues like; what are the major factors among various basic human resource activities like recruitment and selection, compensation, training and development, job security, organizational culture and employees recognition etc. are the most prominent in the insurance sector of Nepal?, has been a thought provoking question to the researcher.

\section{Research Questions}

Based upon the discussion presented on statement of the problem, following research questions are presented for the research work:

1. What are the various factors of human resource practice that has been prevailing in the Nepalese insurance industry?

2. Do these factor change with the moderating variables?

\section{Objectives of the study}

The main objective of this study is to depict concentration towards the factor analysis of HR Practices prevalent in the Nepalese insurance industry. Following are the objectives laid down for this research study:

- To conduct factor analysis of Human resource practices prevailing in Nepalese insurance industry.

- To examine whether these factors varied with the moderating variables.

\section{Theoretical background}

\section{Background of HR Practice}

Human resource management refers to the policies and practices involved in carrying out the HR aspects of a management position including human resource planning, job analysis, recruitment and selection, orientation, compensation, performance appraisal, training and development, and labor relations (Dessler, 2007). HRM is composed of the policies, practices, and systems that influence employees' behavior, attitude, and performance (Noe, Hollenbeck, Gerhart, and Wright, 2007).

A number of writers have been critical of the growing interest in human resource management (HRM) and its impact on workers. Applebaum et al. (2000) found the consistent evidence of a positive association between greater use of various practices and positive employee outcomes. The employee outcomes were measures of trust, intrinsic satisfaction, commitment, general job satisfaction and stress. Ramsey et al. (2000) have reported a thorough test of various competing explanations of the relationship between HR practices, employee attitudes and corporate performance. Guest (1997) has linked HRM and performance whereby Selection, Training, Appraisal, rewards, job design and status and security has been used as HRM Practices and Commitment, Quality and Flexibility as HRM Outcome.

Hendry and Pettigrew (1990) mainly concerned to identify and classify key environmental influences on HRM. Guest (1987) has attempted to capture some of the spirit of this approach by seeking to present it within a coherent framework, specifying some of the links so that the resulting model can at least be 
tested- and possibly disproved. The assumption is that if an integrated set of HRM practices is applied there will be high level of worker performance and will result into positive impact on organizational performance.

\section{Recruitment and selection}

Ongori (2010) pointed recruitment and selection process as the function of human resource management which brings the human resource in the organization. Bratton and Gold (2007) stated that recruitment and selection practices involve two inter-connected and consistent processes. Ofori and Aryeetey (2011) argued recruitment is the process of generating a pool of applicant to apply for employment to an organization and selection is the process by which specific tools are used to choose from a pool of applicants' the most suitable one for the job taking into consideration. Huselid (1995) examined HR practices of high-performance companies and found that attracting and selecting the right employees increases the employee productivity and contributes to a reduction in turnover. Cho et al. (2006) examined pre-employment tests as a key component of selective hiring and found that when employed, these tests can select employees that stay with a company longer. Passing pre-employment tests may give an applicant a stronger sense of belonging to the company, resulting in higher degrees of commitment if employed.

\section{Training and Development}

Training develops the necessary employee skills and ability and increases employee satisfaction and commitment to their jobs and workplace through personal development and organization-based selfesteem (McEvoy 1997). Training and development may be related to firms' performance in many ways. First, training programmes increase the firm specificity to employee skills, which consecutively increases employee productivity as well as reducing job dissatisfaction that results in employee turnover (Huselid, 1995).

Paul and Anantharaman (2003), proposed that career development programmes demonstrate a true organizational interest in the growth of its personnel, which, in turn, stimulates commitment and devotion, subsequently, raising personnel productivity and consequently economical output. Benson, Finegold and Mohrman (2004) examined the effect of corporate investment in tuition reimbursement programmes on employee turnover in a large manufacturing company. Study results demonstrated that tuition reimbursement programmes where employees are able to earn certificates and other credentials had an overall positive effect on turnover.

\section{Compensation Policy}

Performance-based compensation is the dominant HR practice that firms are in order to evaluate and reward employees' actions (Collins and Clark 2003). There is a consensus that performance-based compensation has a positive effect upon employee and organizational performance (Brown, Sturman and Simmering, 2003: Cardon and Stevens, 2004). While performance-based compensation can motivate employees, sometimes employees may be less loyal if they perceive it as a management mechanism to control their behaviour (Lawler and Rhode, 1976; Ahmad and Schroeder, 2003). In such a case, employees are less loyal and committed, thus compensation plans have the opposite effect to the desired outcome (Ahmad and Schroeder, 2003; Rodriguez and Ventura, 2003). Incentive pay based on firm performance was found to increase commitment to organizational goals, employee cohesiveness and a collective orientation (Collins and Clark 2003). Cho, Woods, Jang and Erdem (2006) suggested that incentive plans are effective in decreasing staff turnover rates.

\section{Job Security}

Job security provides an ambiance of self-confidence and self-reliance to the employees. On one hand, studies have found that today's business environments are far from providing job security to their 
employees. For example, Givord and Maurin (2004) in an analysis of the changes in the risks of involuntary job loss in France between 1982 and 2002, found evidence that technological changes contribute to decreasing the incentive to keep workers for long period of time and works to increase job insecurity, On the other hand Job security requires a certain degree of reciprocity (Pfeffer, 1998). According to Pfeffer,: first, a company must signal a clear message that jobs are secure; then, employees believing that this is true, feel confident and commit themselves to expend extra effort for the company's benefit; finally, having learned that job security contributes to its performance, the company continues to invest in job security. Probst (2002) has developed a conceptual model of the antecedents and consequences of job security. Worker characteristics, job characteristics, organizational change and job technology change are included as antecedents. Consequences include psychological health, physical health, organizational withdrawal, unionization activity, organizational commitment and job stress. Job involvement, cultural values, and procedural justices moderate job security.

Kraimer, Wayne and Liden (2005) found that job security was negatively related to full-time employees' perceptions that temporaries were a threat to their jobs. Furthermore, for those employees with low job security, there was a negative relationship between threat perceptions and performance. On the contrary, for those employees with high job security, the study uncovered a positive relation between perceptions and performance.

\section{Organizational culture and employees' recognition}

Organizational culture is the nexus of various aspects like beliefs, values, work styles and relationships that makes one organization different from another. Hofstede's (1984) work related four cultural dimensions have been frequently cited by researchers in the past few decades. He collected data 35 years ago from large multinational companies from forty different countries and concluded that "organizations are cultural bounded" (Gautam, 2013). Hofstede proposed four dimensions of national culture: power distance, collectivism, masculinity/feminity and uncertainty avoidance.

\section{Research design}

\section{Research Methodology}

This research study has applied descriptive and inferential analysis to study about the human resource practices in Nepalese insurance companies. The analysis was based on the responses (opinion and perception) of respondents (employees). Descriptive analysis presented the position of HR practices in Nepalese insurance companies. This study was based on primary data gathered with the help of a questionnaire comprising three sections. The first section contained demographic questions, and the second section contained 31 statements about the human resource management practices. Level of employees (below managerial or managerial level) and the type of insurance (life or non-life) are also considered in this study.

This study incorporates 25 listed insurance companies operating in Nepal. Out of this only, one insurance company (Rastriya Bima Sansthan) was not included in the study because of its comprehensive nature (included life and non-life insurance, which has been considered as a moderating variable in the study). Thus, the study included respondents (employees) from 24 insurance companies, targeted as a sample size.

\section{Limitation of the Study}

In many cases, limitations open the scope for future research. Following are the major limitations of this research work:

- This research work is originated from the empirical study of other researchers. 
- Different scholars and researchers have focused on different types of HR practices. This research work selects and applies only some of them, serving the basis for analysis.

- This Research work is based on the primary data only.

- This study is based on the perception of employees who work at the corporate office only which may not reflect the employees' perception of the whole industry.

\section{Sample statistics of respondents}

\section{Results}

Altogether 500 respondents were selected as a sample, out of which 419 responses were received, however only 322 employees' responses were in a useable form. Thus, the study finally considered 322 respondents as a sample for the study. Sample statistics of respondents includes the respondent Statistics on the basis of organization type and level of employees. Employees as respondents from non-life insurance companies and life insurance companies were 206 (64\%) and 116 (36\%) respectively. Likewise, employees below managerial level and managerial or above the level were $217(67.4 \%)$ and $105(32.6 \%)$ respectively included in the study.

\section{Technique of Analysis}

Collected data were tabulated and essential statistical values like percentage, mean and standard deviation were calculated to draw conclusions. In order to examine the relationship between the factors extracted from various HR practices, correlation test were carried out between factors and to reduce the items factor analysis were carried out. Factor analysis has been carried out to draw the inferences. Under factor analysis, different tests like initial correlation between items, Kaiser-Meyer-Olkin (KMO) and Bartlett's Test, Anti-Image matrix, Initial communalities, Total variance explained and Rotated component Matrix are examined. Principle axis component method is chosen in factor analysis following with Varimax method of rotation and methods are used in factor analysis. Factor loadings are extracted with 0.4 as suppressing value.

This helps to conclude about the degree of association of variables. To test the significance of the result, F-test and $\mathrm{R}^{2}$ test have been carried out. Likewise, independent sample t-test is run to know whether the mean scores are significantly different or not. Decisions are made at $5 \%$ level of significance.

All of the items set for the independent variable i.e., Human Resource Practices (HRP) from five factors were retained after Cronbach's Alpha test. Cronbach alpha's value of 0.917 signified the acceptance of all (31) items for the further study. Out of these five proposed HR practices, four factors; F1, F2, F3, F4 were extracted from the factor analysis. F1 refers to 'Organizational Culture and Employees Recognition (OCER)'; F2 is termed as 'Compensation Policy (CP)', F3 is named as 'Employees Competency Development Policy (ECDP)' and finally F4 is expressed as 'Job Security (JS)'. Significant correlation is found between the extracted factors. Four factors; F1, F2, F3, F4 extracted 31.997\%, 10.046\%, 7.376\% and $6.808 \%$ of the total variance and these four factors together extracted 56.228 percent. This means these four factors altogether explain $56.228 \%$ of the total variance.

Considering the level of employees as a moderating variable; significant differences were noted in the mean scores of the perception of the respondents regarding OCER, ECDP and JS. However, no significant differences were noted in the mean scores of the perception of the respondents regarding $\mathrm{CP}$. While studying the effect of next moderating variable (type of companies), significant differences were noted in the mean scores of the perception of the respondents regarding CP and ECDP but no significant 
differences were prevalent in the mean scores of the perception of the respondents regarding OCER and JS.

Considering the descriptive statistics, 'Job Security (JS)' was composed of the most agreed statements. It was responded with the highest average mean value of 4.025. Similarly, 'Compensation Policy (CP)' with average mean score of 3.695, was the next factor, which was highly comprised of the agreeing statement. This was followed by the third factor 'Employees Competency Development Policy (ECDP)' with average mean score of 3.365. Finally, the fourth factor 'Organizational culture and Employees recognition (OCER)' was the factor with the least agreed statement.

\section{Conclusion, Implication and direction for future research}

The reason of one of the training and development item being combined with the items of recruitment and development may be because both of these factors were related to the selection of the best employees which are when maintained and developed (through regular training and development activities) would help the organization to develop competent employees. With this logic, researcher has named the factor as 'Employees Competency development Policy'. Though the number of factors extracted from the factor analysis has reduced to four from the proposed five constructs, extracted factors have been able to extract at least one of the items from each of the proposed constructs. However, the reduction in the number of extracted factors may be because of two reasons; Firstly, factor analysis reduces the number of items. Secondly, the number of factors may have increased if the number of respondents' could have increased. Nepalese insurance industry maintains good HR practice, like they recruit and select competitively, pay salary and benefits on time, concern about employees' job security, etc.

The study may be helpful in gaining insight about the human resource aspects at any level of the organization. This research work, based on the insurance industry, has given some important references regarding the human resource practice. For future research, human resource practice can be linked with other variables like employee turnover, job satisfaction, motivation, employees' commitment, employees' engagement, stress management and organizational performance to broaden the knowledge on HR practice. This research has wide range of application which can be applied in almost all type of organizations (Government, public, private, profit or non-profit, product or service oriented, Tourism and hospitality, banking and health sector, etc.).

\section{References}

Adhikari D. R. (1992), Human resource management for public enterprises: a model for designing jobs in Nepalese factories, Nomos Wirtschaft, Germany.

Adhikari, D. R., \& Gautam, D. K. (2011) Employees' commitment and organizational performance in Nepal: A typological framework. SEBON Journal, Vol, 1-17.

Adhikari, D. R., \& Gautam, D. K. (2010), Labour legislations for improving quality of work life in Nepal, International Journal of Law and Management, 52, 1, 40-53.

Adhikari, D. R. (2004), Human resource environment in Nepal, paper presented at the $5^{\text {th }}$ international industrial relation association congress, Seoul.

Adhikari, D. R. (2008), Human resource management, Buddha Publication, Kathmandu.

Adhikari, D. R. (2010), Human resource development for performance management, International Journal of Productivity and performance Management, 49, 4, 306-324.

Agrawal, G. R., (1983), Innovative human resource management: case studies of Nepal, CEDA, Kathmandu. 
Ahmad, S., and Schroeder, R.G. (2003), "The impact of Human Resources Management Practices on Operational Performance: Recognizing Country and Industry Differences, "Journal of Operations Management, 21, 1943.

Appelbaum,E. and Berg, P. (2000), "High performance work systems: giving workers a stake", in Blair, M. And Kochan, T. (Eds). The new Relationship: Human Capital in the American Corporation, Brookings Institution Press, Washington, DC.

Benson, G.S., Finegold, D., and Mohrman, S.A. (2004), "You Paid for the skills, Now Keep them: Tuition Reimbursement and Voluntary Turnover," Academy of Management Journal, 47, 3, 315-331.

Bratton, J. \& Gold, J. (2007). Human resource management: Theory and practice, 2nd Edition, London: MacMillan.

Brown, M.P., Sturman, M.C., and Simmering, M.J. (2003), "Compensation Policy and Organizational Performance: The Efficiency, Operational, and Financial Implications of Pay levels and Pay Structure." Academy of Management Journal, 46, 6, 752-762.

Cardon, M.S., and Stevens, C.E. (2004), "Managing Human Resources in Small Organizations: What do we Know?" Human Resource Management Review, 14, 295-323.

Cho, S., Woods, R.H., Jang, S.C. and Erdem, M. (2006), "Measuring the Impact of Human Resources Management Practices on Hospitality Firms' Performances", International Journal of Hospitality Management, Vol. 25, pp. 262-77.

Collins, C.J., and Clark, K.D. (2003), "Strategic Human Practices, Top Management Commitment, Team Social Networks and Firm performance: The role of Human Resource Practices in Creating Organizational Competitive Advantage," Academy of Management Journal, 46, 6, 740-751.

Dessler, G., Human Resource Management. New Delhi: Prentice Hall of India Private Limited, 2007.

Gautam, D.K. (2013), “Hoftede's Cultural Dimension after 35 Years: Business Practices and Paradoxical Proverbs in Nepal: A Case Study of NABIL Nepal", The International Journal of Nepalese Academy of Management, Vol. 1 No.1, pp. 87-114.

Givord, P., and Maurin, E. (2004),"Changes in Job Security and their Causes: An Empirical Analysis for France, 1982-2002," European Economic Review, 48, 595-615.

Guest, D.E. (1987) 'Human Resource Management and Industrial Relations', Journal of Management Studies, 24: 503-21.

Guest, D.E. (1997), "Human resource management and performance: a review and research agenda", The International Journal of Human Resource Management, Vol. 8 No. 3, pp. 263-76.

Hendry, C. And Pettigrew, A. (1990) 'Human Resource management: an agenda for the 1990s'. International Journal of Human Resource Management, 1(1): 17-43.

Hofstede, G. (1984), Culture's consequences: international differences in work related values, Beverly Hills, CA: Sage.

Huselid, M.A. (1995) 'The Impact of Human Resource management Practices on Turnover, Productivity and Corporate Financial Performance', Academy of Management Journal, 38:635-70.

Koirala, U., (1989), Workers participation in management, Unpublished Ph. D. Thesis, Panjab University, India. 
Kraimer, M.L., Wayne, S.J., Liden, R.C., and Sparrowe, R.T (2005) "The Role of Job Security in Understanding the Relationship between Employees' perceptions of Temporary Workers and Employees' Performance," Journal of Applied Psychology, 90, 2, 389-398.

Lawler, E.E., and Rhode, J.G. (1976), Information and Control in Organizations, Pacific Palisades, C.A: Goodyear Publishing Company.

McEvoy, M.G. (1997), "Organizational Change and Outdoor Management Education", Human Resource Management, 36, 2, 235-250.

Noe, et al., (2007). Human Resource Management: Gaining a competitive advantage. USA: McGraw-Hill, 2007.

Ofori, D. \& Aryeetey, M. (2011). Recruitment and selection practices in small and medium enterprises: Perspectives from Ghana, International Journal of Business Administration, 2 (3), 45-60.

Ongori, H. (2010). Recruitment and selection practices in SMEs: empirical evidence from a developing country perspective', Advances in Management, 3 (2), 52-58.

Pant, P. R., (1993), Survey report: Nepal in Asian dynamism through human resource development, Asian Productivity Organization, Tokyo.

Paudel, S. P., (1992), A study of decision making in Nepalese Enterprises, Unpublished Ph. D. Thesis, University of Delhi, India.

Paul, A.K., and Anantharaman, R.N. (2003), "Impact of People Management Practices on Organizational Performance: Analysis of a Causal Model," International Journal of Human Resource Management, 14, 7, 1246-1266.

Pfeffer, J. (1998), “Seven Practices of Successful Organizations,” California Management Review, 40, 2, 96-124.

Probst, T.M. (2002), "The Impact of Job Insecurity on Employee Work Attitudes, Job Adaptation, and Organizational Withdrawal Behaviours," in The Psychology of Work: Theoretically Based Empirical Research, eds. J.M Breti and F. Drasgow, Mahwah, NJ: Lawrence Erlbaum Associates, pp. 141-168.

Ramsey H, Scholaries D, Harley B (2000) Employees and High Work Performance Systems: Testing Inside the Black Box British Journal of Industrial Relations 38 (4), 501-31

Rodriguez, J.M., and Ventura, J. (2003), "Human Resource management Systems and Organizational Performance: An Analysis of the Spanish manufacturing Industry," International Journal of Human Resource Management, 14, 7, 1206-1226.

Shrestha, R.P., (1991), Personnel management in private industries in Nepal, Unpublished Ph. D. Thesis, Tribhuvan University, Nepal.

Tiwari, M. N., (1984), Personnel administration in manufacturing public enterprises of Nepal, Unpublished Ph. D. Thesis, Panjab University, India.

Upadhyaya, N. P., (1981), Personnel management in manufacturing public enterprises of Nepal, unpublished Ph. D. Thesis, Panjab University, India. 


\section{Appendices}

Table No.1 Respondents statistics on the basis of level of employees

\begin{tabular}{|l|l|l|}
\hline Level of employees & Frequency & Percent \\
\hline Below Managerial level & 217 & 67.4 \\
\hline Managerial Level & 105 & 32.6 \\
\hline Total & $\mathbf{3 2 2}$ & $\mathbf{1 0 0}$ \\
\hline
\end{tabular}

Table no. 2 Respondents statistics on the basis of type of company

\begin{tabular}{|l|l|l|}
\hline Insurance Type & Frequency & Percent \\
\hline Non-Life & 206 & 64 \\
\hline Life & 116 & 36 \\
\hline Total & 322 & 100 \\
\hline
\end{tabular}

Table 3 Reliability Statistics for independent variables

\section{Reliability Statistics}

Cronbach's Alpha

0.917

\section{$\mathrm{N}$ of Items}

31

Table no. 4 KMO and Bartlett's Test

\begin{tabular}{|l|l|l|}
\hline \multicolumn{2}{|l|}{ KMO and Bartlett's Test } & 0.851 \\
\hline Kaiser-Meyer-Olkin Measure of Sampling Adequacy & Approx. Chi-Square & 1510.562 \\
\cline { 2 - 3 } Bartlett's Test of Sphericity & Df & 120 \\
\cline { 2 - 3 } & Sig. & 0.00 \\
\hline
\end{tabular}

Table no. 5 Eigen values and Total variance Explained

\begin{tabular}{|c|c|c|c|}
\hline \multicolumn{3}{|c|}{ Initial Eigen values } \\
\hline S.N. & Total & \% of Variance & Cumulative \% \\
\hline $\mathbf{1}$ & $\mathbf{5 . 1 2}$ & $\mathbf{3 1 . 9 9 7}$ & $\mathbf{3 1 . 9 9 7}$ \\
\hline $\mathbf{2}$ & $\mathbf{1 . 6 0 7}$ & $\mathbf{1 0 . 0 4 6}$ & $\mathbf{4 2 . 0 4 3}$ \\
\hline $\mathbf{3}$ & $\mathbf{1 . 1 8}$ & $\mathbf{7 . 3 7 6}$ & $\mathbf{4 9 . 4 1 9}$ \\
\hline $\mathbf{4}$ & $\mathbf{1 . 0 8 9}$ & $\mathbf{6 . 8 0 8}$ & $\mathbf{5 6 . 2 2 8}$ \\
\hline 5 & 0.976 & 6.102 & 62.33 \\
\hline 6 & 0.866 & 5.413 & 67.742 \\
\hline 7 & 0.829 & 5.182 & 72.924 \\
\hline 8 & 0.627 & 3.918 & 76.842 \\
\hline 9 & 0.608 & 3.801 & 80.643 \\
\hline 10 & 0.594 & 3.712 & 84.354 \\
\hline 11 & 0.52 & 3.25 & 87.605 \\
\hline 12 & 0.475 & 2.967 & 90.572 \\
\hline 13 & 0.421 & 2.631 & 93.203 \\
\hline 14 & 0.397 & 2.484 & 95.686 \\
\hline 15 & 0.357 & 2.234 & 97.92 \\
\hline 16 & 0.333 & 2.08 & 100 \\
\hline
\end{tabular}


Table no. 6 Rotation Component Matrix

\begin{tabular}{|c|c|c|c|c|}
\hline \multicolumn{5}{|l|}{ Rotated Component Matrix(a) } \\
\hline & \multicolumn{4}{|c|}{ Component } \\
\hline & 1 & 2 & 3 & 4 \\
\hline My idea often accounts in the staff meeting & 0.803 & & & \\
\hline I've represented my department in many formal meetings & 0.673 & & & \\
\hline Company takes my suggestion to solve the problem & 0.668 & & & \\
\hline Meetings are frequently conducted between employees and employers & 0.653 & & & \\
\hline I am allowed to comment on my senior's decision & 0.52 & & & \\
\hline My senior treats me with respect & 0.484 & & & \\
\hline The company has provided insurance facility to me & & 0.691 & & \\
\hline I am satisfied with the salary & & 0.682 & & \\
\hline Retirement benefits of this company are attractive & & 0.659 & & \\
\hline I get bonus from the company & & 0.623 & & \\
\hline The recruitment and selection process in this organization is impartial & & & 0.75 & \\
\hline Selection process is based on merit system & & & 0.635 & \\
\hline Company provides training and development program regularly & & & 0.606 & \\
\hline Interview panel recruits and selects the employees of this co. & & & 0.583 & \\
\hline Employees that perform modestly do not get fired & & & & 0.843 \\
\hline The organization focus on job security & & & & 0.818 \\
\hline \multicolumn{5}{|l|}{ Extraction Method: Principal Component Analysis. } \\
\hline Rotation Method: Varimax with Kaiser Normalization. & & & & \\
\hline
\end{tabular}

Table no. 7 Extracted Factors with their variables and their name

Factor I

My idea often accounts in the staff meeting

I've represented my department in many formal meetings

Company takes my suggestion to solve the problem

Meetings are frequently conducted between employees \& employers

I am allowed to comment on my senior's decision

My senior treats me with respect

Factor II

The company has provided insurance facility to me

I am satisfied with the salary

Retirement benefits of this company are attractive

I get bonus from the company

\section{Factor III}

The recruitment and selection process in this organization is impartial

Selection process is based on merit system

Company provides training and development program regularly

Organization

Culture

and

Employees'

Recognition

(OCER)

Interview panel recruits and selects the employees of this co.

\section{Factor IV}

Employees that perform modestly do not get fired

Job Security

The organization focus on job security 
Test of Normality

Table no. 8: Table showing the Normality Test.

\begin{tabular}{|l|l|r|r|r|r|}
\hline \multicolumn{7}{|c|}{ One-Sample Kolmogorov-Smirnov Test } \\
\hline & & Factor 1 & Factor 2 & Factor 3 & \multicolumn{1}{|c|}{ Factor 4 } \\
\hline $\mathrm{N}$ & & 322 & 322 & 322 & 322 \\
\hline Normal Parameters ab & Mean & 3.072 & 3.6957 & 3.3657 & 4.0248 \\
\hline & Std. Deviation & 0.8401 & 0.7323 & 0.7054 & 0.9599 \\
\hline Most Extreme Differences & Absolute & 0.079 & 0.141 & 0.106 & 0.241 \\
\hline & Positive & 0.079 & 0.075 & 0.106 & 0.155 \\
\hline & Negative & -0.075 & -0.141 & -0.081 & -0.241 \\
\hline Kolmogorov-Smirnov Z & & 1.422 & 2.537 & 1.893 & 4.329 \\
\hline Asymp. Sig. (2-tailed) & & 0.035 & 0 & 0.002 & 0 \\
\hline a. Test distribution is Normal. & & & & \\
\hline b. Calculated from data. & & & & \\
\hline
\end{tabular}

Table No. 9: Showing the Group Statistics of the Factors as per the type of Company (Life and Non-Life)

\begin{tabular}{|c|c|c|c|c|c|}
\hline \multicolumn{6}{|c|}{ Group Statistics } \\
\hline & Insurance Type & $\mathbf{N}$ & Mean & Std. Deviation & Std. Error Mean \\
\hline \multirow{2}{*}{$\begin{array}{c}\text { Factor } 1 \\
\text { (OCER) }\end{array}$} & Non-Life & 206 & 3.0262 & 0.86734 & 0.06043 \\
\hline & Life & 116 & 3.1534 & 0.78656 & 0.07303 \\
\hline \multirow{2}{*}{$\begin{array}{l}\text { Factor } 2 \\
(\mathrm{CP})\end{array}$} & Non-Life & 206 & 3.6177 & 0.76695 & 0.05344 \\
\hline & Life & 116 & 3.8341 & 0.64685 & 0.06006 \\
\hline \multirow{2}{*}{$\begin{array}{l}\text { Factor } 3 \\
\text { (ECDP) }\end{array}$} & Non-Life & 206 & 3.2852 & 0.69907 & 0.04871 \\
\hline & Life & 116 & 3.5086 & 0.69699 & 0.06471 \\
\hline \multirow{2}{*}{$\begin{array}{l}\text { Factor } 4 \\
\text { (JS) }\end{array}$} & Non-Life & 206 & 3.949 & 0.98331 & 0.06851 \\
\hline & Life & 116 & 4.1595 & 0.90554 & 0.08408 \\
\hline
\end{tabular}


Table No. 10: t-test statistics of the factors regarding the type of company:

\begin{tabular}{|c|c|c|c|c|c|c|c|c|c|c|}
\hline \multicolumn{11}{|c|}{ Independent Samples Test } \\
\hline & & \multicolumn{5}{|c|}{ Levene's Test for Equality of Variances } & \multicolumn{4}{|c|}{ t-test for Equality of Means } \\
\hline & & & & & & \multicolumn{5}{|c|}{$95 \%$ Confidence Interval of the Difference } \\
\hline & & $\mathrm{F}$ & Sig. & $\mathrm{T}$ & Df & $\begin{array}{l}\text { Sig. } \\
(2- \\
\text { tailed }) \\
\end{array}$ & $\begin{array}{l}\text { Mean } \\
\text { Difference }\end{array}$ & $\begin{array}{l}\text { Std. Error } \\
\text { Difference } \\
\end{array}$ & Lower & Upper \\
\hline & $\begin{array}{l}\text { Equal } \\
\text { variances } \\
\text { assumed } \\
\end{array}$ & 0.773 & 0.38 & -1.306 & 320 & 0.192 & -0.12723 & 0.09742 & -0.31889 & 0.06442 \\
\hline $\begin{array}{l}\text { Factor } 1 \\
\text { (OCER) }\end{array}$ & $\begin{array}{l}\text { Equal } \\
\text { variances not } \\
\text { assumed }\end{array}$ & & & -1.342 & 258.43 & 0.181 & -0.12723 & 0.09479 & -0.3139 & 0.05943 \\
\hline \multirow[b]{2}{*}{$\begin{array}{l}\text { Factor } 2 \\
(\mathrm{CP})\end{array}$} & $\begin{array}{l}\text { Equal } \\
\text { variances } \\
\text { assumed } \\
\end{array}$ & 4.226 & 0.041 & -2.567 & 320 & 0.011 & -0.21633 & 0.08428 & -0.38216 & $\begin{array}{c}- \\
0.05051\end{array}$ \\
\hline & $\begin{array}{l}\text { Equal } \\
\text { variances not } \\
\text { assumed } \\
\end{array}$ & & & -2.691 & 273.12 & 0.008 & -0.21633 & 0.08039 & -0.37459 & $\begin{array}{c}- \\
0.05807 \\
\end{array}$ \\
\hline \multirow[b]{2}{*}{$\begin{array}{r}\text { Factor } 3 \\
(\text { ECDP) } \\
\end{array}$} & $\begin{array}{l}\text { Equal } \\
\text { variances } \\
\text { assumed }\end{array}$ & 0.205 & 0.651 & -2.756 & 320 & 0.006 & -0.22343 & 0.08106 & -0.38291 & $\begin{array}{c}- \\
0.06394\end{array}$ \\
\hline & $\begin{array}{l}\text { Equal } \\
\text { variances not } \\
\text { assumed }\end{array}$ & & & -2.759 & 239.14 & 0.006 & -0.22343 & 0.08099 & -0.38298 & $\begin{array}{c}- \\
0.06387 \\
\end{array}$ \\
\hline \multirow[b]{2}{*}{$\begin{array}{c}\text { Factor } 4 \\
\text { (JS) }\end{array}$} & $\begin{array}{l}\text { Equal } \\
\text { variances } \\
\text { assumed } \\
\end{array}$ & 2.028 & 0.155 & -1.896 & 320 & 0.059 & -0.21045 & 0.11098 & -0.42881 & 0.0079 \\
\hline & $\begin{array}{l}\text { Equal } \\
\text { variances not } \\
\text { assumed } \\
\end{array}$ & & & -1.94 & 255.28 & 0.053 & -0.21045 & 0.10846 & -0.42404 & 0.00313 \\
\hline \multirow[b]{2}{*}{$\begin{array}{l}\text { DV } \\
\text { (EOC) }\end{array}$} & $\begin{array}{l}\text { Equal } \\
\text { variances } \\
\text { assumed } \\
\end{array}$ & 0.007 & 0.935 & -1.102 & 320 & 0.271 & -0.07224 & 0.06557 & -0.20124 & 0.05677 \\
\hline & $\begin{array}{l}\text { Equal } \\
\text { variances not } \\
\text { assumed }\end{array}$ & & & -1.12 & 250.77 & 0.264 & -0.07224 & 0.06447 & -0.19921 & 0.05474 \\
\hline
\end{tabular}


Table No. 11: Showing the Group Statistics of the Factors as per the employees' level

\begin{tabular}{|l|l|c|c|c|c|}
\hline \multicolumn{7}{|c|}{ Group Statistics } \\
\hline & Position/level of employees & $\mathbf{N}$ & Mean & Std. Deviation & Std. Error Mean \\
\hline $\begin{array}{l}\text { Factor 1 } \\
\text { (OCER) }\end{array}$ & Below Managerial Level & 217 & 2.9051 & 0.80853 & 0.05489 \\
\cline { 2 - 6 } & Managerial Level & 105 & 3.4171 & 0.8015 & 0.07822 \\
\hline $\begin{array}{l}\text { Factor } 2 \\
(\text { CP) }\end{array}$ & Below Managerial Level & 217 & 3.6947 & 0.74407 & 0.05051 \\
\cline { 2 - 6 } $\begin{array}{l}\text { Factor 3 } \\
\text { (ECDP) }\end{array}$ & Managerial Level & 105 & 3.6976 & 0.71109 & 0.06939 \\
\hline \multirow{2}{*}{$\begin{array}{l}\text { Factor 4 } \\
\text { (JS) }\end{array}$} & Below Managerial Level & 217 & 3.2938 & 0.70451 & 0.04783 \\
\cline { 2 - 6 } & Managerial Level & 105 & 3.5143 & 0.68713 & 0.06706 \\
\hline
\end{tabular}

Table no. 12: t-test statistics of the factors regarding the level of employees:

\begin{tabular}{|c|c|c|c|c|c|c|c|c|}
\hline \multicolumn{9}{|c|}{ Independent Samples Test } \\
\hline & & \multirow{2}{*}{\multicolumn{4}{|c|}{$\begin{array}{c}\text { Levene's Test for Equality of } \\
\text { Variances }\end{array}$}} & \multicolumn{3}{|c|}{ t-test for Equality of Means } \\
\hline & & & & & & $95 \%$ & onfidence Int & val of the Difference \\
\hline & & $\mathrm{F}$ & Sig. & $\mathrm{T}$ & Df & $\begin{array}{l}\text { Sig. (2- } \\
\text { tailed) }\end{array}$ & $\begin{array}{l}\text { Mean } \\
\text { Difference }\end{array}$ & Std. Error Difference \\
\hline \multirow{2}{*}{$\begin{array}{l}\text { Factor } 1 \\
\text { (OCER) }\end{array}$} & $\begin{array}{l}\text { Equal variances } \\
\text { assumed }\end{array}$ & 0.006 & 0.939 & -5.343 & 320 & 0 & -0.51207 & 0.09585 \\
\hline & $\begin{array}{l}\text { Equal variances } \\
\text { not assumed }\end{array}$ & & & -5.359 & 207.421 & 0 & -0.51207 & 0.09555 \\
\hline \multirow{2}{*}{$\begin{array}{l}\text { Factor } 2 \\
(\mathbf{C P})\end{array}$} & $\begin{array}{l}\text { Equal variances } \\
\text { assumed }\end{array}$ & 0.719 & 0.397 & -0.033 & 320 & 0.973 & -0.00292 & 0.0872 \\
\hline & $\begin{array}{l}\text { Equal variances } \\
\text { not assumed }\end{array}$ & & & -0.034 & 214.413 & 0.973 & -0.00292 & 0.08583 \\
\hline \multirow{2}{*}{$\begin{array}{l}\text { Factor } 3 \\
\text { (OECD) }\end{array}$} & $\begin{array}{l}\text { Equal variances } \\
\text { assumed }\end{array}$ & 0.232 & 0.631 & -2.654 & 320 & 0.008 & -0.22051 & 0.08309 \\
\hline & $\begin{array}{l}\text { Equal variances } \\
\text { not assumed }\end{array}$ & & & -2.677 & 210.488 & 0.008 & -0.22051 & 0.08236 \\
\hline \multirow{2}{*}{$\begin{array}{l}\text { Factor } 4 \\
\text { (JS) }\end{array}$} & $\begin{array}{l}\text { Equal variances } \\
\text { assumed }\end{array}$ & 6.224 & 0.013 & -2.61 & 320 & 0.009 & -0.29524 & 0.1131 \\
\hline & $\begin{array}{l}\text { Equal variances } \\
\text { not assumed }\end{array}$ & & & -2.881 & 265.857 & 0.004 & -0.29524 & 0.10246 \\
\hline
\end{tabular}

